\title{
Trends and variability in extreme precipitation indices over Maghreb countries
}

\author{
Y. Tramblay ${ }^{1}$, S. El Adlouni ${ }^{2}$, and E. Servat ${ }^{1}$ \\ ${ }^{1}$ IRD - HydroSciences Montpellier (UMR5569, CNRS, IRD, UM1, UM2), Case MSE, Place Eugène Bataillon, \\ 34095 Montpellier Cedex 5, France \\ ${ }^{2}$ Université de Moncton, Département de Mathématique et Statistique, NB, Canada
}

Correspondence to: Y. Tramblay (yves.tramblay@ird.fr)

Received: 2 May 2013 - Published in Nat. Hazards Earth Syst. Sci. Discuss.: 26 July 2013

Revised: 13 November 2013 - Accepted: 19 November 2013 - Published: 13 December 2013

\begin{abstract}
Maghreb countries are highly vulnerable to extreme hydrological events, such as floods and droughts, driven by the strong variability of precipitation. While several studies have analyzed the presence of trends in precipitation records for the Euro-Mediterranean basin, this study provides a regional assessment of trends on its southernmost shores. A database of 22 stations located in Algeria, Morocco and Tunisia with between 33 and $59 \mathrm{yr}$ of daily precipitation records is considered. The change points and trends are analyzed for eleven climate indices, describing several features of the precipitation regime. The issue of conducting multiple hypothesis tests is addressed through the implementation of a false discovery rate procedure. The spatial and interannual variability of the precipitation indices at the different stations are analyzed and compared with largescale atmospheric circulation patterns, including the North Atlantic Oscillation (NAO), western Mediterranean Oscillation (WEMO), Mediterranean Oscillation (MO) and El Niño-Southern Oscillation (ENSO). Results show a strong tendency towards a decrease of precipitation totals and wet days together with an increase in the duration of dry periods, mainly for Morocco and western Algeria. On the other hand, only a few significant trends are detected for heavy precipitation indices. The NAO and MO patterns are well correlated with precipitation indices describing precipitation amounts, the number of dry days and the length of wet and dry periods, whereas heavy precipitation indices exhibit a strong spatial variability and are only moderately correlated with large-scale atmospheric circulation patterns.
\end{abstract}

\section{Introduction}

Maghreb countries (Algeria, Morocco and Tunisia) in northern Africa are vulnerable to extreme hydrological events such as floods and droughts. Like other Mediterranean countries they are prone to violent flood episodes caused by torrential rainfall, which may have catastrophic effects with a very high number of casualties (Llasat et al., 2010). The deadliest events that occurred in these three countries during the last fifty years were the 2001 flood near Algiers (Algeria), which caused more than 700 fatalities (Argence et al., 2008); the 1969 floods in the region of Kairouan (Tunisia), with between 150 and 400 fatalities (Poncet, 1970; Guillaud and Trabelsi, 1991); and the 1995 flood in the Ourika valley (Morocco), with over than 200 fatalities (Saidi et al., 2003). On the other hand, the strong interannual variability of precipitation, which is one of the most important features of the Mediterranean climate (Lionello, 2012), causes dry spells of varying length threatening the water resources in these countries. For the last two decades, there is a growing awareness about these extreme events (Bouaicha and Benabdelfadel, 2010), and a growing concern about the possible increase in their intensity or frequency (Douglas et al., 2008). In particular for floods, as a significant increase in the vulnerability of the populations was observed in Maghreb countries during the last decades (Fig. 1), similar to what was observed on the whole African continent by Di Baldassarre et al. (2010).

In the Maghreb region, there is limited data coverage and most of the rivers are regulated for either water resources or flood protection. There is a need to analyze the longterm trends and variability in precipitation that are causing 


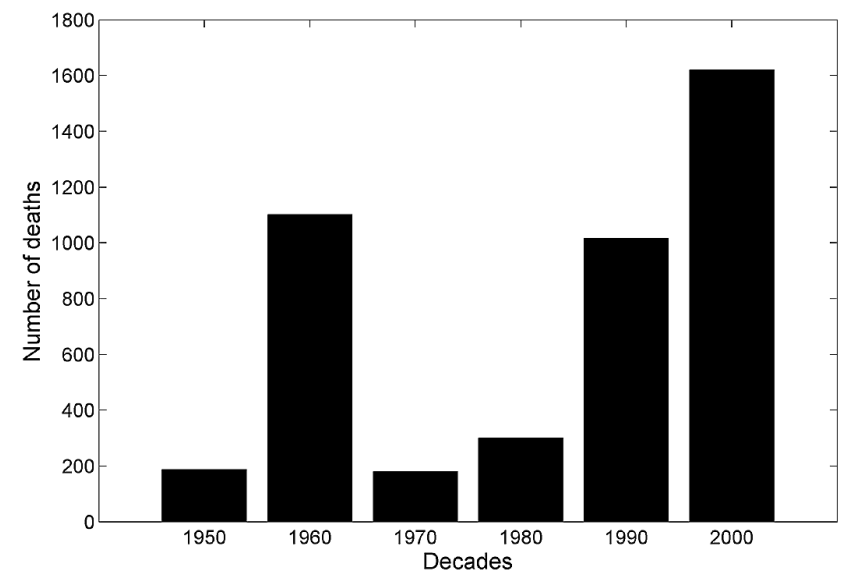

Fig. 1. Fatalities caused be floods between 1950 and 2009 in Algeria, Morocco and Tunisia (data from EM-DAT: The OFDA/CRED International Disaster Database - www.emdat.net - Université catholique de Louvain, Brussels, Belgium).

floods or drought periods. Several studies have analyzed the regional precipitation trends in large data sets over Europe (Moberg and Jones, 2005), West Africa (Servat et al., 1999) or southern Africa (New et al., 2006) during the last decades. However a few studies have considered the southern or eastern parts of the Mediterranean basin (Zhang et al., 2005; Donat et al., 2013), which are very vulnerable to climate change (Schilling et al., 2012). Previous research on precipitation in Maghreb countries has mainly focused on interannual variability and the relationships with large-scale patterns such as the North Atlantic Oscillation (NAO) or El Niño-Southern Oscillation (ENSO), for water resource management purposes (El Hamly and Sebbari, 1998; Kingumbi et al., 2005; Knippertz et al., 2003; Driouech et al., 2010; Mebarki 2010; Meddi et al., 2010; Ouachani et al., 2011). Indeed, several studies have shown that precipitation in the Mediterranean basin is influenced by local characteristics, such as elevation and topography (Hidalgo-Muñoz et al., 2010; Acero et al., 2011; Lionello, 2012), but also by largescale circulation such as the NAO (Xoplaki et al., 2004; Mariotti and Dell'Aquila, 2012; Angulo-Martínez and Beguería, 2012), the Mediterranean Oscillation (MO) (Conte, 1989), the WEMO (Martín-Vide and Lopez-Bustins, 2006) and ENSO (Meddi et al., 2010; Ouachani et al., 2011). Meddi et al. (2010) observed a decrease in precipitation totals in north-west Algeria after 1970 related to the ENSO index. In Morocco, very dry years have also been observed after 1970, in relation with positive NAO anomalies (El Hamly et al., 1998; Knippertz et al., 2003). Driouech et al. (2013), Schilling et al. (2012) and Donat et al. (2013) reported a long-term trend towards drier conditions for Morocco, but also for a few stations a possible increase in precipitation totals after 1980. Tramblay et al. (2012) noted the absence of trends in annual maximum precipitation in Morocco and the link of annual maximum precipitation in some stations with the NAO and MO indexes. In Tunisia, Kingumbi et al. (2005) reported a reduction of annual rainfall between 1976 and 1989 and Ouachani et al. (2011) observed a link between precipitation variability and the ENSO index.

For the Mediterranean basin, several studies observed an increase in the occurrence and the severity of droughts during the 20th century (Sousa et al., 2011; Hoerling et al., 2012). However in the western part of the Mediterranean basin, precipitation has not shown a homogeneous tendency in the last decades. Alpert et al. (2002) reported an increase in heavy precipitation in Italy and Spain between 1951 and 1995, but Toreti et al. (2010) observed for six locations in France, Italy, Greece, and Cyprus a decreasing trend in the number of heavy precipitation events between 1950 and 2006. Reiser and Kutiel (2010) found no significant trends in precipitation indices in 40 sites across the Mediterranean basin between 1931 and 2006, with the notable exception in Algier (Algeria) where they observed a decrease in the number of rain spells and total precipitation. In Spain, several studies observed a general decrease in annual precipitation since the 1950 s, in the number of rainy days, and precipitation intensity, and an increase in the duration of dry spells. On the contrary, the frequency of heavy rainfall events and their contribution to annual precipitation events has not changed at most observatories, nor shown a decreasing trend (LopezMoreno et al., 2010; Rodrigo, 2010; Acero et al., 2010; Gallego et al., 2011). However, Hidalgo-Muñoz et al. (2010) and Acero et al. (2011) reported positive trends in the heavy rainfall event's magnitude over the south-eastern Mediterranean coast, corresponding to the region of Andalusia. In Italy, Brunetti et al. (2004) reported a decrease in the number of wet days associated with an increase in precipitation intensity and Bonaccorso et al. (2005) and Caloiero et al. (2011) observed in southern Italy negative trends in winter rainfall amounts and in annual maximum daily precipitation during the last 50 yr. In the south of Portugal, Costa et al. (2009) noted an increase in the length of dry spells between 1955 and 1999, but no significant trends in heavy precipitation. Similarly in southern France, Pujol et al. (2007) and Tramblay et al. (2013) did not detect changes or trends in heavy rainfall events during the last $50 \mathrm{yr}$.

The main objective of this study is to analyze the regional trends in precipitation during the last $50 \mathrm{yr}$, with a focus on extreme dry and wet events, in long time series of precipitation in Maghreb countries. It is necessary to distinguish the possible climate change signal from the increased vulnerability, in order to improve the mitigation and adaptation strategies. In addition to the trend detection, the link between precipitation characteristics and large-scale atmospheric circulation is also analyzed, in an attempt to characterize the interannual variability. The two main questions addressed by this study are (i) is the stationary hypothesis valid on the long term for different precipitations indices? and (ii) Can the observed interannual variability be explained 
by large-scale circulation indices, such as the NAO, WEMO, $\mathrm{MO}$ or ENSO? The trend analysis and the dependences with large-scale atmospheric circulation are investigated using robust statistics, taking into account the serial and cross correlations in the data set and also the issue of repeating multiple statistical tests. The following section describes the different data sets considered for this study. The Sect. 3 details the statistical tests applied to the precipitation data and the Sect. 4 presents the results.

\section{Study area and data sets}

Here we consider the long daily precipitation series maintained by the governmental hydrological services of Algeria, Morocco and Tunisia, who are in charge of dams and water regulation structures (Fig. 2). Daily precipitation data have been provided by the hydrological services of Algeria (Agence Nationale des Resources Hydrauliques, ANRH), Morocco (Direction de la Recherche et de la Planification de l'Eau, DRPE), and Tunisia (Direction Générale des Ressources en Eau, DGRE). The longest data series available between 1950 and 2009 have been provided. These stations are usually located near dams or reservoirs, so it is unlikely that these stations were displaced. They are routinely used to estimate the return levels for extreme precipitation and to evaluate the interannual water resources availability. The daily data for the Melilla station (Spain) located in northern Morocco was downloaded from ECA\&D. Data and metadata are available at http://eca.knmi.nl.

The raw data record underwent a data quality control procedure, to check for missing data records and measurements errors such as the reporting of unrealistic precipitation values. Each station data has been carefully scrutinized, in particular to look for obvious breaks, absurd values and missing data by visual inspection. The stations that were subsequently selected did not have more than $5 \%$ missing daily data between September and May. The years with more than $5 \%$ missing daily data during this period have been removed. In the whole area, there is a strong seasonality signal with most of the precipitation occurring during late fall and winter. The summer months of June, July and August are not considered in the analysis since there is almost no precipitation during these months in all the stations and they have a very large number of missing data. After this quality check, 22 stations were selected in the three countries (Table 1). The median length of records is $45 \mathrm{yr}$, with complete data in almost all of the stations between 1970 and 2002 (Fig. 3). Most stations are located in the northern part of Africa, in the rainiest and most populated areas of Algeria, Morocco and Tunisia. As shown on the map of the rain gauge stations (Fig. 2), this is an area where several major flood events have been reported between 1984 and 2012. Therefore, it is important to check the presence of trends in the precipitation records, since the stationarity hypothesis is often assumed for the management of water resources.

In addition, different climatic indices have been considered in an attempt to explain the observed interannual variability of precipitation at the regional scale. They include the NAO (Hurrell, 1995), MO (Conte, 1989) and WEMO (Martín-Vide and Lopez-Bustins, 2006) indices. These indices have been computed from daily sea level pressure grids by Angulo-Martínez and Beguería (2012). The North Atlantic Oscillation index (NAOi) was calculated as the normalized difference between the time series of sea level pressure (SLP) recorded at two points in the south-west Iberian Peninsula (Gibraltar, $35^{\circ} \mathrm{N}, 5^{\circ} \mathrm{W}$ ) and south-west Iceland (Reykjavik, $65^{\circ} \mathrm{N}, 20^{\circ} \mathrm{W}$ ). The Mediterranean Oscillation index (MOi), as defined by Palutikof (2003), was calculated as the daily normalized difference between the SLP at Gibral$\operatorname{tar}\left(35^{\circ} \mathrm{N}, 5^{\circ} \mathrm{W}\right)$ and Lod, Israel $\left(30^{\circ} \mathrm{N}, 35^{\circ} \mathrm{E}\right)$. The western Mediterranean Oscillation index (WEMOi) was calculated as the daily normalized difference between the SLP at Gibraltar $\left(35^{\circ} \mathrm{N}, 5^{\circ} \mathrm{W}\right)$ and Parma $\left(45^{\circ} \mathrm{N}, 10^{\circ} \mathrm{E}\right)$. For ENSO, since different versions of the index exist (Ouachani et al. 2011), here is considered the Multivariate ENSO Index (MEi) proposed by Wolter and Timlin (2011) available online: http://www.esrl.noaa.gov/psd/enso/mei/. The MEi integrates more information than other ENSO indices and it better reflects the nature of the coupled ocean-atmosphere system in the ENSO phenomenon. Some other teleconnection patterns are known to influence precipitation in the Mediterranean region to a lesser extend, such as the East Atlantic or the Scandinavian patterns, but they are not considered in the present study since their influence is mainly noticeable in the northern part of the Mediterranean basin (Lionello, 2012).

\section{Methodology}

\subsection{Precipitation indices}

Several precipitation indices, similar to those of ETCCDI (Klein Tank et al., 2002; New et al., 2006 and http://cccma. seos.uvic.ca/ETCCDI/) are considered. The selected indices include:

1. The total precipitation (PRCPTOT)

2. The ratio of wet days (R1mm)

3. The simple daily precipitation intensity (SDII)

4. The Annual maximum precipitation (RX1day)

5. The 95th percentile of daily precipitation (Prec95p)

6. Fraction of the annual total precipitation above Prec95p (R95pTOT)

7. The maximum length of dry spells (CDD) 


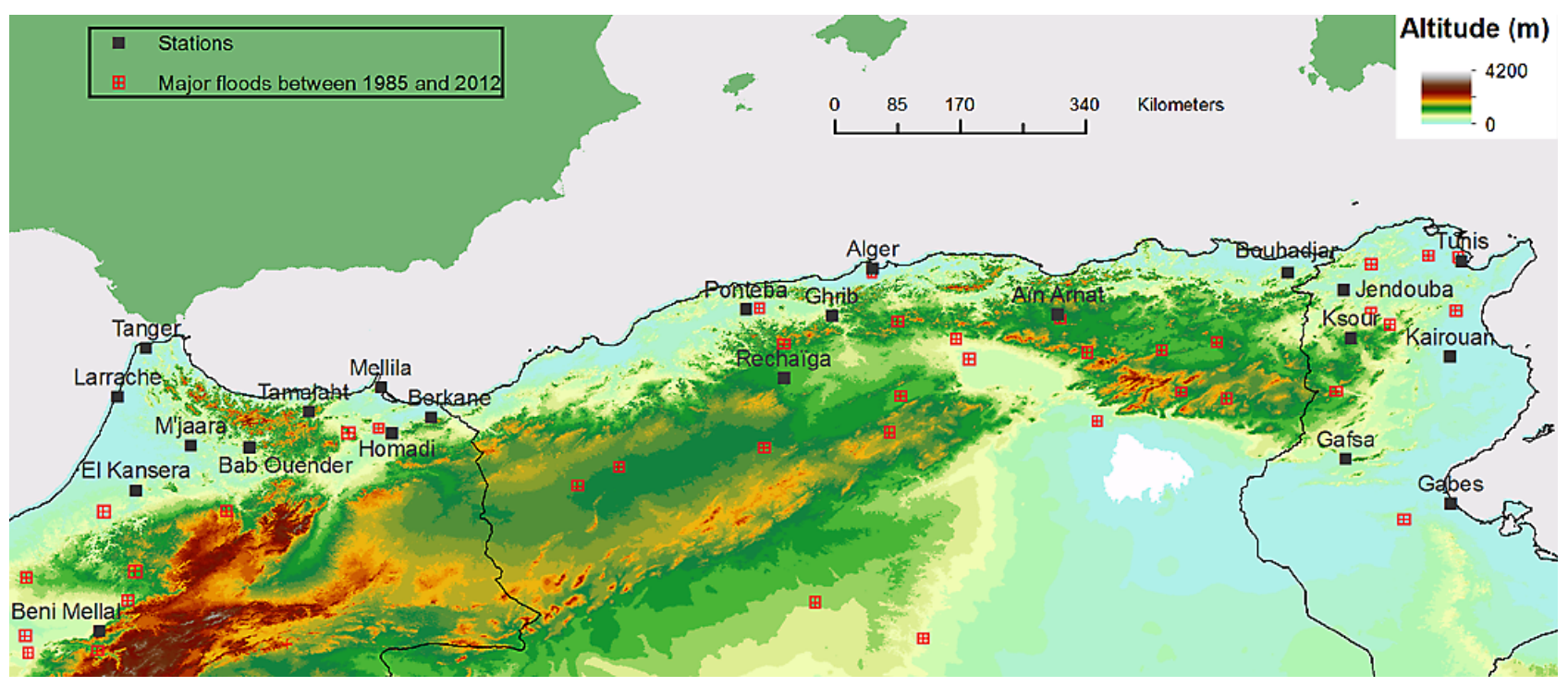

Fig. 2. Map of the selected stations and centroids of the areas affected by floods between 1984 and 2012 (data from G. R. Brakenridge, "Global Active Archive of Large Flood Events", Dartmouth Flood Observatory, University of Colorado, http://floodobservatory.colorado. edu/Archives/index.html).

Table 1. Stations with precipitation data (the full years are those with less than $5 \%$ missing data during the hydrological year).

\begin{tabular}{lllrrrr}
\hline ID & Name & Country & $\begin{array}{r}\text { Altitude } \\
(\mathrm{m})\end{array}$ & Beginning & End & $\begin{array}{r}\text { Number of } \\
\text { full years }\end{array}$ \\
\hline 1 & Rechaiga & Algeria & 830 & 1948 & 2005 & 39 \\
2 & Alger & Algeria & 140 & 1951 & 2005 & 46 \\
3 & Ain Arnat & Algeria & 1100 & 1970 & 2005 & 37 \\
4 & Bouhadjar & Algeria & 0 & 1945 & 2005 & 37 \\
5 & Ghrib & Algeria & 460 & 1968 & 2005 & 36 \\
6 & Ponteba & Algeria & 140 & 1968 & 2005 & 38 \\
7 & Bab Ouender & Morocco & 312 & 1956 & 2006 & 44 \\
8 & M'jaara & Morocco & 96 & 1958 & 2006 & 45 \\
9 & Beni Mellal & Morocco & 537 & 1950 & 2007 & 54 \\
10 & Berkane & Morocco & 160 & 1959 & 2006 & 44 \\
11 & El Kansera & Morocco & 100 & 1950 & 2006 & 44 \\
12 & Homadi & Morocco & 230 & 1950 & 2004 & 46 \\
13 & Tamalaht & Morocco & 275 & 1970 & 2005 & 34 \\
14 & Larrache & Morocco & 5 & 1942 & 2011 & 49 \\
15 & Tanger & Morocco & 5 & 1972 & 2006 & 33 \\
16 & Mellila & Morocco & 47 & 1907 & 2009 & 46 \\
17 & Gabes & Tunisia & 4 & 1950 & 2009 & 57 \\
18 & Gafsa & Tunisia & 300 & 1950 & 2009 & 58 \\
19 & Jendouba & Tunisia & 143 & 1950 & 2009 & 59 \\
20 & Kairouan & Tunisia & 55 & 1950 & 2009 & 58 \\
21 & Ksour & Tunisia & 720 & 1950 & 2009 & 49 \\
22 & Tunis & Tunisia & 66 & 1950 & 2009 & 58 \\
\hline
\end{tabular}

8. The mean length of dry spells (CDDm)

9. The maximum length of wet spells (CWD)

10. The mean length of wet spells (CWDm)

11. Number of events above Prec95p (R95p)
The indices have been computed for wet days, i.e. when the daily precipitation is exceeding $1 \mathrm{~mm}$ during the hydrological years (from September to May). The R1mm and PRCPTOT indices are not describing extreme precipitation, however they are frequently used to assess the homogeneity of precipitation data series (Wijngaard et al., 2003), and this 


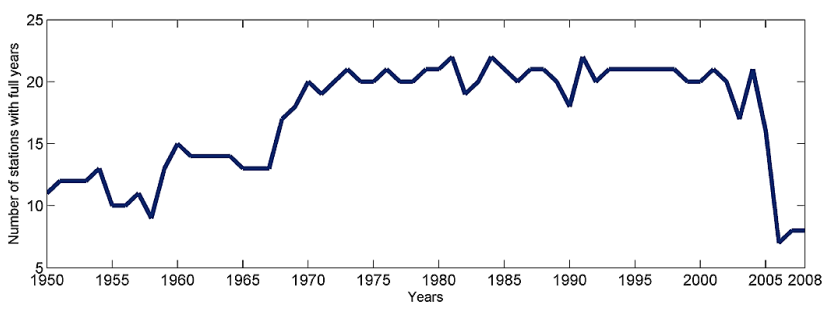

Fig. 3. Number of stations with full years (less than $5 \%$ missing data) between 1950 and 2008.

is the reason why they are included in the analysis. Figure 4 shows the box plots of these two variables together with the annual maximum precipitation. The most striking feature in all the stations is the strong interannual variability of precipitation, with great variations in precipitation amounts and extremes depending on the year.

A temporal declustering scheme has been adopted for the computation of the R95p to ensure the independence of consecutive threshold exceedances (Tramblay et al. 2013). Indeed the trend and change point test results could be questioned if the observations are dependent (Khaliq et al. 2006), that is, if several days that are belonging to the same extreme event are considered in analysis. The mean number of consecutive days exceeding the threshold of Prec95p in all the stations is 1.73 days (maximum 2.18 and minimum 1.37). Therefore, a minimum of 2 days between consecutive threshold exceedances is adopted for the computation of R95p in each station. Thresholds above the 95th percentiles have also been tested (for example the 99th percentile). However due to the strong interannual variability, they lead to a very low annual number of threshold exceedances which are concentrated only in a few years. Consequently, thresholds above the 95th percentile are not considered in the present study.

\subsection{Pettitt test for change points}

There is no homogeneity correction method specifically designed for daily precipitation time series and no consensus about the best method to be used (Beaulieu et al., 2007; Toreti et al., 2010). However, homogeneity is a crucial aspect when dealing with trend detection or time series analysis. If the monotonic trends are likely caused by long-term climate change, step changes in precipitation series may be considered doubtful and possibly caused by station relocation or changes in the station instrumentation. The Pettitt (1979) test is able to detect potential change points in the mean of time series; it has been widely used with precipitation data (Servat et al., 1999; Klein Tank et al., 2002; Wijngaard et al., 2003; Beaulieu et al., 2007; Villarini et al., 2011). To test the null hypothesis $H_{0}$ of "no change in the mean of the series tested", the statistical significance of the test is computed using the approximate limiting distribution for continuous dis- tributions provided by Pettitt (1979). The Pettitt test is applied to the time series of all indices defined in Sect. 3.1.

\subsection{Mann-Kendall test for trends}

The Mann-Kendall (MK) test (Mann 1945) is used for the trend detection. For large sample sizes, Mann (1945) and Kendall (1975) have documented that the test statistic $S$ is approximately normally distributed. The null hypothesis $H_{0}$ for the test is "there is no trend in the time series". Several studies have shown that the presence of serial correlation in the data may affect the results of trend analysis by increasing the variance of $S$ (Douglas et al., 2000; Khaliq et al., 2009; Renard et al., 2009). Hamed and Rao (1998) proposed correcting the variance of the MK test statistic $S$ by using an effective sample size that reflects the effect of serial correlation. This correction was applied in the present study, with the serial correlation estimated from the detrended series as recommended by Yue and Wang (2004). Khaliq et al. (2009) have shown that this approach is able to handle not only the autoregressive of order 1 structure (AR(1)) but also higher order serial dependencies.

In addition the method of Sen (1968) is considered to estimate the magnitude of the slope of detected trends:

$b_{\mathrm{se}_{n}}=\operatorname{Median}\left[\left(Y_{i}-Y_{j}\right) /(i-j)\right]$,

where $Y_{i}$ and $Y_{j}$ are data points $i$ and $j$. With $N$ values in the time series, there is as many as $n=N(N-1) / 2$ slope estimates and $b_{\mathrm{se}_{n}}$ is the median of these $n$ values.

\subsection{Correlations with atmospheric circulation indices}

The correlations between the precipitation indexes and largescale indicators are investigated by means of the nonparametric Spearman's (1904) test. It is a special case of the Pearson's correlation coefficient, in which the data are replaced by their ranks. This test is well suited for monotonically related variables, even when their relationship is not linear, as it is required in the case of Pearson's correlation coefficient. The null hypothesis $H_{0}$ for the test is "there is no correlation in between the two variables".

\subsection{False discovery rate and field significance of trend results}

The significance level $\alpha$ for a statistical test is the probability of committing a Type I error (i.e. rejecting the null hypothesis when it is true). Nevertheless, this probability is related to a single test and is no longer valid when multiple tests are conducted (Livezey and Chen, 1983; Ventura et al., 2004). Consequently, as the number of tests being conducted increase, more significant values are found. The $p$ values of different independent tests follows a binomial distribution with sample size $n$ and the probability of correctly accepting the null hypothesis is $1-\alpha$. The purpose of the false discovery rate (FDR) procedure (Benjamini and Hochberg, 1995) is 

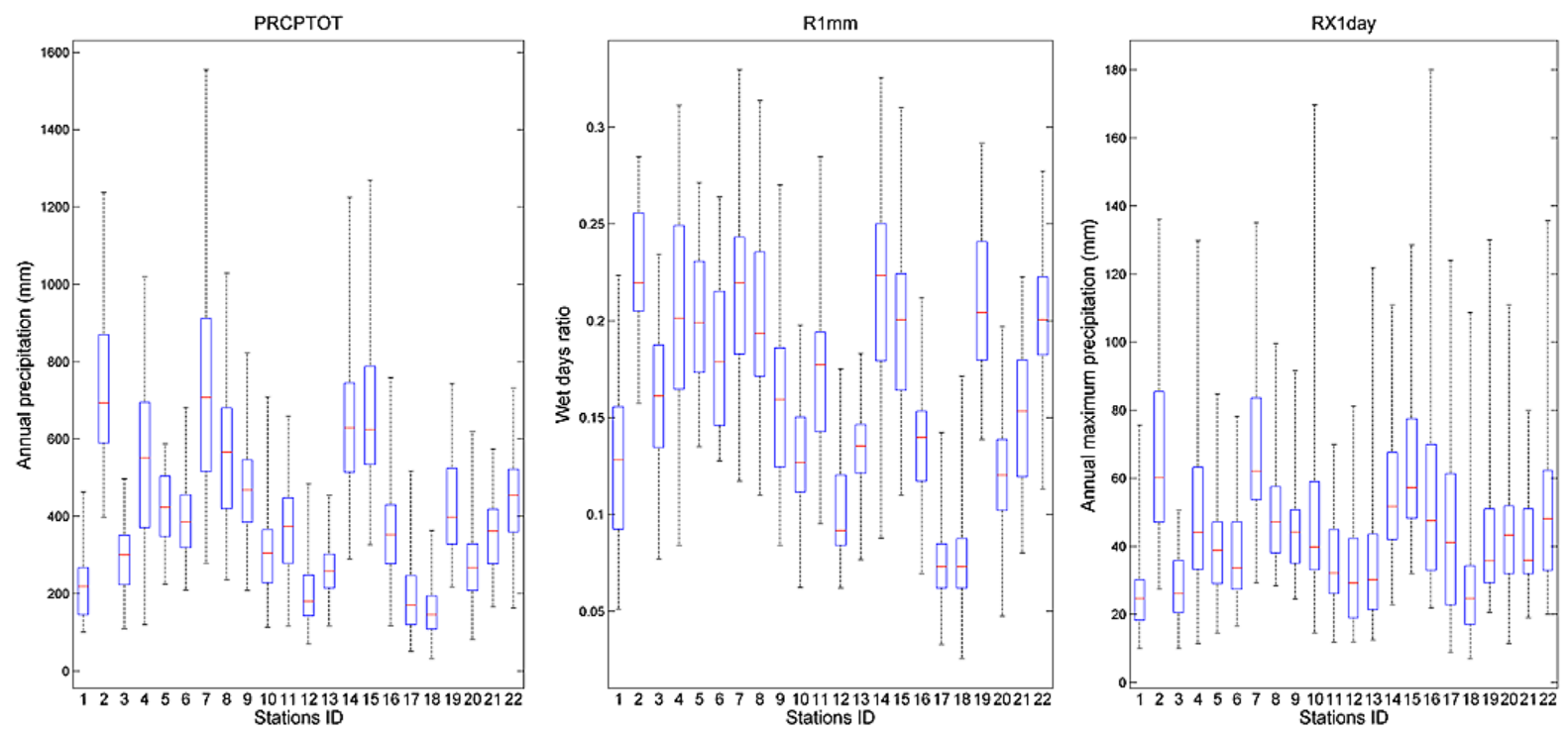

Fig. 4. Box plots showing the PRCPTOT, R1mm and RX1day precipitation indices for the 22 rain gauges considered in this study. The boxes have lines at the lower quartile, median and upper quartile values; the whiskers extend from each end to the most extreme values. The ID and name of the stations are reported in Table 1.

to identify a set of at-site significant tests by controlling the expected proportion of falsely rejected null hypotheses that are actually true (Renard et al., 2008; Khaliq et al., 2009).

In addition to the issue of repeating several times the same statistical test, the presence of cross correlation may also affect the test results, by artificially increasing the number of significant trends, and consequently it requires field significance testing (Douglas et al., 2000; Pujol et al., 2009). Field significance testing allows for the determination of the percentage of tests that are expected to show a trend, at a given local significance level, purely by chance. Wilks (2006), Renard et al. (2008) and Khaliq et al. (2009) demonstrated that the original FDR procedure of Benjamini and Hochberg (1995) is robust to positive cross correlations and can work with any statistical test for which one can generate a $p$ value.

Therefore the FDR procedure of Benjamini and Hochberg (1995) is used here to identify the stations where the statistical test results are field significant.

Consider testing $H_{1}, H_{2}, \ldots H_{m}$ based on the corresponding $p$ values $P_{1}, P_{2}, \ldots P_{m}$. Let $P_{1} \leq P_{2} \leq \ldots \leq P_{m}$ be the ordered $p$ values and denotes by $H_{i}$ the null hypothesis corresponding to $P_{i}$. Let $k$ be the largest $i$ for which

$P_{i} \leq \frac{i}{m} \alpha_{\text {global }}$

Then reject all $H_{i}$ for $i=1,2, \ldots k$.

$\alpha_{\text {global }}$ is the global significance level, it is set here to 0.05 , the same as the local confidence level considered for the Pettitt, Mann-Kendall and Spearman tests. The field significance is declared by this method when at least one null hypothesis is rejected at the global significance level.

\section{Results}

\subsection{Serial and cross correlations}

The presence of autocorrelation in time series may affect the change point (Beaulieu et al., 2012) or trend detection test results (Douglas et al., 2000; Khaliq et al., 2009) by increasing the probability of the null hypothesis to be rejected. Consequently, the presence of lag-1 autocorrelation in the time series of the different indices is first tested. Results indicate that a very limited number of stations exhibit autocorrelation, only for R1mm in Berkane and Tanger and PRCPTOT in Rechaiga. In all cases, it is a significant positive lag-1 autocorrelation. The indices of extremes such as RX1day, Prec95p or CDD do not exhibit any serial correlations. Therefore, there is a very limited influence of autocorrelation in the present analysis.

To evaluate the spatial structure of dependence of the different precipitation indices, for each of the 11 indices a crosscorrelation matrix was build for the period 1970-2002, when most stations have complete years. There are significant cross correlations for most indices, with higher correlations among the stations for PRCPTOT, R1mm and CDDm in comparison with heavy precipitation indices (RX1day or Prec95p). The spatial correlations for the different indices have been also analyzed with climatological variograms, assuming the isotropy of the space (Bastin et al., 1984). The variogram allows quantifying the degree of spatial dependence of a field. For each index and each year between 1970 and 2002, a variogram scaled by the variance of the field is computed. The mean variogram obtained for each precipitation index is then fitted with a spherical model, which is a convenient tool for 

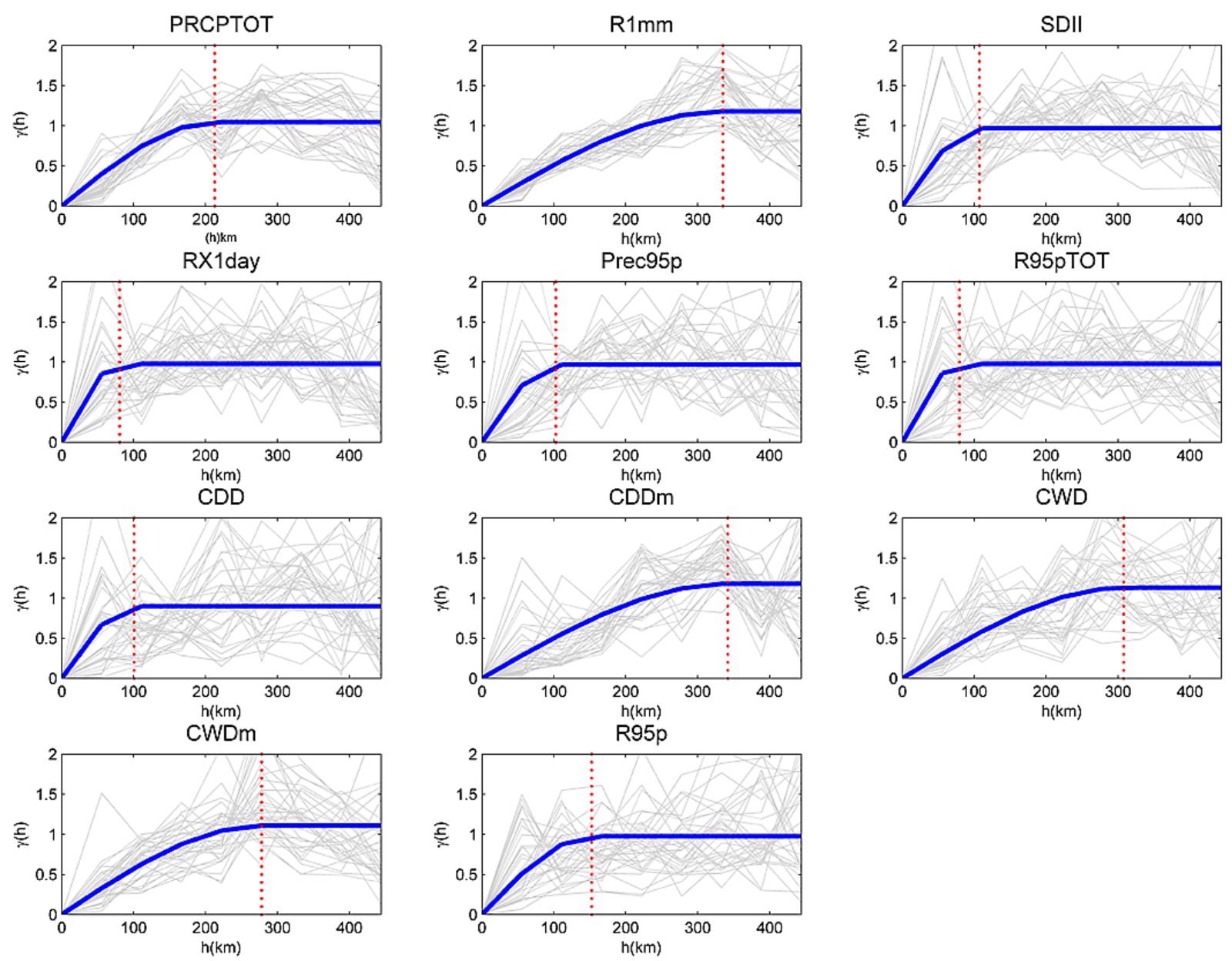

Fig. 5. Scaled empirical variograms $(\gamma)$ computed for the indices each year (grey lines). The thick blue lines represent the fitted spherical variogram models, the red dotted lines are the values of the range parameters for the variogram models.

precipitation kriging since it provides a value of the decorrelation distance, given by the value of the range parameter (Lebel and Laborde, 1988). The climatological variograms are presented in Fig. 5. Overall, while the indices describing intense precipitation (SDII, RX1day, Prec95p, R95pTOT, R95p) show high temporal and spatial variability, with range parameters less than $150 \mathrm{~km}$, the indices describing rainfall amounts or the duration of dry and wet periods (PRCPTOT, $\mathrm{R} 1 \mathrm{~mm}, \mathrm{CDD}, \mathrm{CDDm}, \mathrm{CWD}, \mathrm{CWDm}$ ) exhibit less temporal variability and a much greater decorrelation distance, up to $350 \mathrm{~km}$ for R1mm and CDDm.

Significant correlations also exist between the different precipitation indices. The mean PRCPTOT and the mean R1mm at the different stations are well positively correlated, with $\rho=0.93$ between the two variables. There is also a strong correlation between the annual precipitation totals (PRCPTOT) and annual daily maximums (RX1day). The Spearman correlation coefficient between the two variables is significant at the $5 \%$ significance level in every station, with an average value $\rho=0.58$ (with minimum and maxi- mum values respectively of 0.36 and 0.86 ). The correlation coefficient is itself an inverse function of the mean annual precipitation, with highest values for stations with low annual precipitation. For the most arid stations where the mean annual precipitation is below $200 \mathrm{~mm}$ (Gabes and Gafsa), the annual maximum daily precipitation can represent up to $25 \%$ of the annual precipitation totals. When considering the fraction of the annual total precipitation above the 95th percentile, this ratio rises up to $58 \%$ of the annual totals. The same ratio was observed by Toreti et al. (2010) in the EuroMediterranean region.

\subsection{Change points and trends}

The presence of change points, indicating possible homogeneity breaks, has been tested with the Pettitt test. A special focus is put on the PRCPTOT and R1mm indices, since they are often used to check the homogeneity of precipitation data (Wijngaard et al., 2003). In cases when both a significant monotonic trend and a change point are detected, the 
Pettitt test is applied on the detrended series, since the presence of a monotonic trend could lead to the false detection of a change point. To remove the trends, the least-squares fit of a straight line to the data is computed and the resulting function is subtracted from the data. For PRCPTOT and R1mm this procedure has been applied to the stations of Rechaiga, Ponteba Bab Ouender, Beni Mellal, El Kansera and Larache where a monotonic trend was present. For the two indices, the smallest local $p$ value $(0.05)$ is obtained for $\mathrm{R} 1 \mathrm{~mm}$ at the Berkane station, yet non significant at the $5 \%$ level. Therefore no significant change points are detected and the hypothesis of homogeneity is valid for all the stations selected. The same conclusion holds true for all indices.

The trend test results are presented in Table 2, showing the Sen slope estimates for each station and each index, if the trends are significant. As expected by the FDR approach, there are fewer significant trends at the global significance level (in bold) than at the local significance level. There is a strong evidence of a global drying tendency in most of the stations. The trends are more pronounced in the western part of the study area, including Morocco and west Algeria (Fig. 6). The trend test results indicate an increase of the ratio of dry days $(\mathrm{R} 1 \mathrm{~mm})$ and the duration of dry spells (CDD, CDDm), a decrease of precipitation totals (PRCPTOT) and the duration of precipitation episodes (CWD, CWDm). In particular, field-significant trends at the global level are identified for R1mm in 9 stations, out of 11 with local significant trends, for CDDm in 8 stations and for PRCPTOT in 5 stations (Table 2). As reported by Schilling et al. (2012) and Donat et al. (2013), the recent years after 1980 have seen positives anomalies in precipitation amounts for some areas in northern Morocco. Indeed for the stations of Berkane, Homadi, Tamalaht, Mellila a slight increase, not statistically significant, in PRCPTOT can be observed after 1980 (Fig. 7). However, since some hydrological years such as 1995/1996 and 2009/2010 have been very wet in this area, this could partly explain this apparent increase over the recent years. It is unclear, due to the low density of stations and the lengths of the available time series, if this is a regional pattern or just localized behavior in some stations.

On the other hand, a few significant trends are detected for the heavy precipitation indices. In some stations (Ponteba, Bab Ouender, Rechaiga, Ponteba, Beni Mellal), negative trends are detected in precipitation intensity (SDII), annual maximum precipitation (RX1day), in the 95th percentile of precipitation (Prec95p) or in the relative part of the heavy precipitation events in annual precipitation totals (R95pTOT). However, these trends are only significant at the local level. For the annual maximum precipitation, there is a field-significant trend towards a decrease only for the Rechaiga station (Table 2). Therefore, the hypothesis of stationarity for annual maximum precipitation remains valid for most stations (Fig. 8). There are a few stations with a negative tendency in the probability of observing a heavy rainfall event (R95p), as observed in other parts of the Mediter-
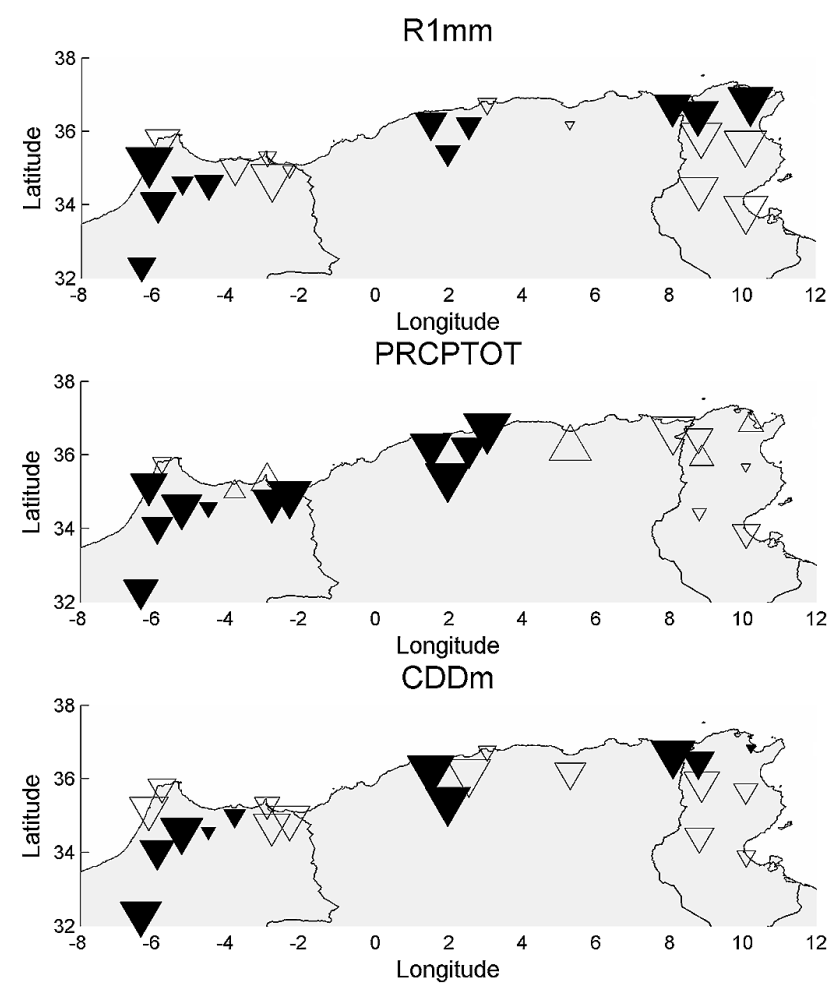

Fig. 6. Maps of the long-term trends detected for the indices R1mm, PRCPTOT and CDDm. The size of the triangles is proportional to the Sen slopes estimated on the full length of the time series. The triangles filled with black are the stations where the trend is significant at the $5 \%$ level according to the Mann-Kendall test. The actual values of the Sen slopes are in Table 2 .

ranean basin by Toreti et al. (2010). However the only station for which field significance at the $5 \%$ level is achieved is Rechaiga. These trend results are consistent with those obtained in Algiers by Reiser and Kutiel (2010).

\subsection{Relationships with large-scale circulation indices}

The correlations between the different precipitation indices and the NAOi, WEMOi, MOi and MEi have been analyzed. The presence of trends may affect the correlation analysis and since the focus here is on the co-variability of the different precipitation and large-scale circulation indices, the indices have been detrended if a significant trend was present. This is the case of the NAOi and MOi, which are showing a long-term positive trend in particular after the 1970s (Hurell, 1995; Mariotti and Dell'Aquila, 2012). Since the negative phase of these indices is associated with frontal conditions that are triggering rainfall in the Mediterranean basin, the more frequent occurrence of positive phases after 1970 may be the explanation of the drying trends reported in the previous section. Different time aggregation periods for the computation of the climate indices have been tested. When considering annual averages of the large-scale circulation indices 
Table 2. Sen slope estimates for each station and each index, only in cases when the Mann-Kendall test detected a significant trend at the local $5 \%$ level. Among them, the field-significant trends at the global $5 \%$ level are in bold. In italic are indicated the trends towards wetter conditions, all other numbers are the trends towards drier conditions.

\begin{tabular}{|c|c|c|c|c|c|c|c|c|c|c|c|}
\hline Stations & $\begin{array}{l}\mathrm{R} 1 \mathrm{~mm} \\
(\%)\end{array}$ & $\begin{array}{l}\text { PRCPTOT } \\
(\mathrm{mm})\end{array}$ & $\begin{array}{l}\text { SDII } \\
\left(\mathrm{mm} \mathrm{day}^{-1}\right)\end{array}$ & $\begin{array}{l}\text { RX1day } \\
(\mathrm{mm})\end{array}$ & $\begin{array}{l}\text { Prec95p } \\
(\mathrm{mm})\end{array}$ & $\begin{array}{l}\text { R95pTOT } \\
(\%)\end{array}$ & $\begin{array}{l}\text { CDD } \\
\text { (days) }\end{array}$ & $\begin{array}{l}\text { CDDm } \\
\text { (days) }\end{array}$ & $\begin{array}{l}\text { CWD } \\
\text { (days) }\end{array}$ & $\begin{array}{l}\text { CWDm } \\
\text { (days) }\end{array}$ & $\begin{array}{l}\text { R95p } \\
\text { (days) }\end{array}$ \\
\hline $\begin{array}{l}\text { Rechaiga } \\
\text { Algier }\end{array}$ & -0.0023 & $\begin{array}{l}-\mathbf{4 . 9 6 6 7} \\
-4.5793\end{array}$ & & -0.4615 & -0.1604 & -0.0019 & & 0.15441 & -0.0455 & -0.00635 & $\begin{array}{l}-\mathbf{0 . 0 6 2 5} \\
-0.0385\end{array}$ \\
\hline AinArnat & & & & & 0.2110 & & & & & & \\
\hline Bouhadjar & -0.0023 & & & & & & 0.5 & 0.07902 & -0.0667 & & \\
\hline Ghrib & -0.0015 & -2.7342 & & & & & & & & & \\
\hline Ponteba & -0.0024 & $-\mathbf{5 . 5 7 1 4}$ & & -0.3778 & -0.1363 & -0.0014 & & 0.09225 & -0.0500 & -0.00579 & -0.0625 \\
\hline BabOuender & -0.0018 & -11.8136 & -0.0790 & -0.6254 & & & 0.29412 & 0.06737 & & & -0.0455 \\
\hline Mjaara & -0.0013 & -4.5714 & & & & & 0.34549 & 0.05891 & & & \\
\hline $\begin{array}{l}\text { BeniMellal } \\
\text { Berkane }\end{array}$ & -0.0015 & $\begin{array}{l}-\mathbf{4 . 8 2 0 0} \\
-1.8227\end{array}$ & & -0.2114 & & & 0.25 & 0.07955 & -0.0256 & -0.0042 & -0.0263 \\
\hline $\begin{array}{l}\text { ElKansera } \\
\text { Homadi }\end{array}$ & -0.0018 & -4.3449 & & & & & 0.54545 & 0.08162 & & & \\
\hline Tamalaht & & & & & & & & 0.09766 & & & \\
\hline Larache & -0.0018 & -3.5182 & 0.0266 & & & & & & & -0.00755 & \\
\hline Tanger & & & & & -0.1935 & & & & & & \\
\hline Melilla & & & 0.0557 & & & & & & & & \\
\hline Gabes & & & & & & & & & & & \\
\hline Gafsa & & & & & & & & & & & \\
\hline Jendouba & -0.0006 & & & & & & & 0.01883 & & & \\
\hline Kairouan & & & & & & & & & & & \\
\hline Ksour & & & & & & & & & & & \\
\hline Tunis & -0.00030 & & & & & & & 0.0205 & & & \\
\hline
\end{tabular}
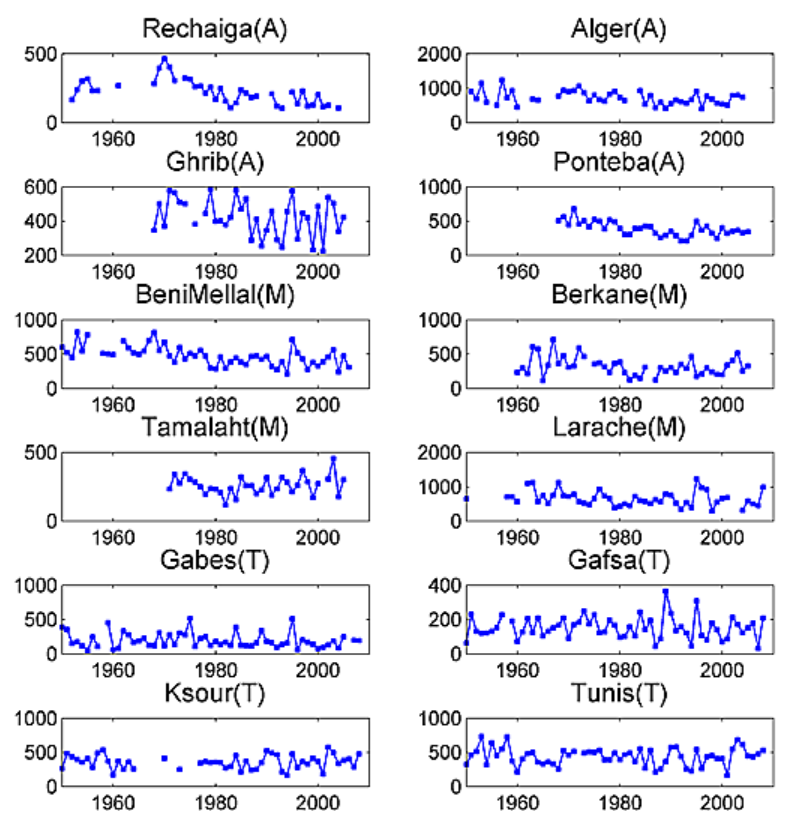
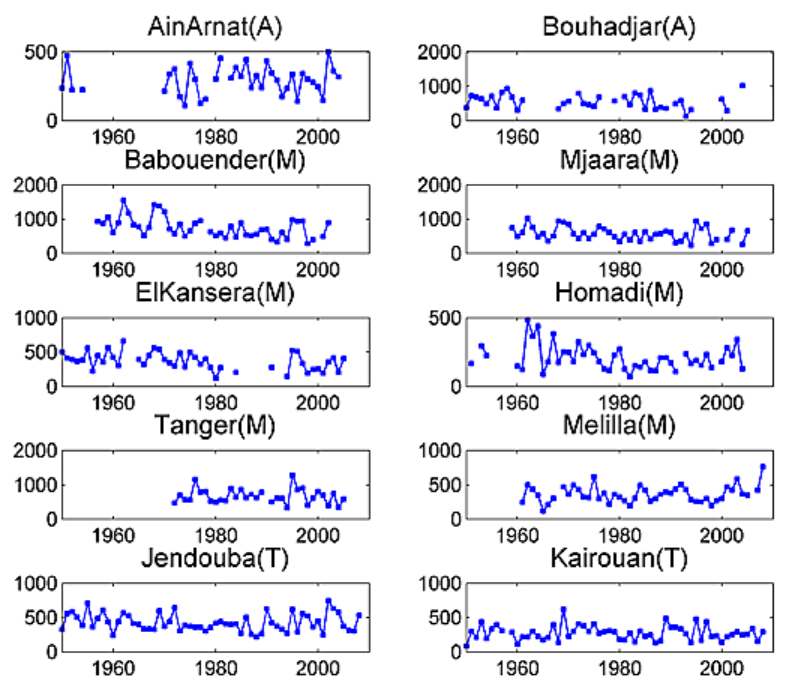

Fig. 7. Times series of the annual total precipitation (PRCPTOT, in $\mathrm{mm}$ ) at the different stations.

(from September to August), almost no significant correlations with precipitation indices are found. The largest number of significant correlations is obtained when considering the extended winter season (from November to March) averages of the NAOi, WEMOi, MOi and MEi. It must be noted that similar correlation results have been obtained when av- eraging the different atmospheric indices from November to March or from December to February, indicating the robustness of the signal during the extended winter season.

The results of the correlation analysis are presented in Fig. 9, showing for each precipitation indices the number of local and global significant correlations with the different 

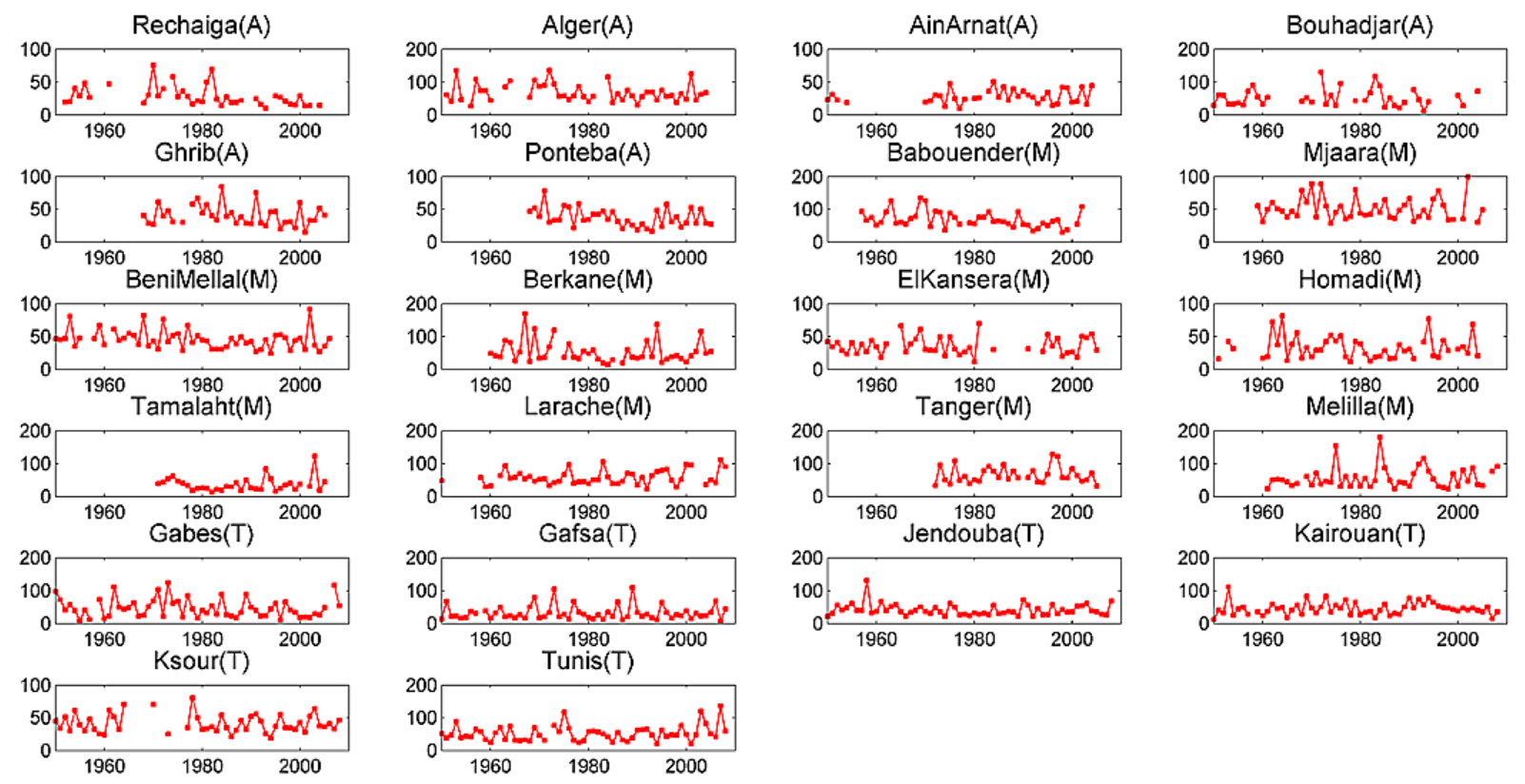

Fig. 8. Times series of the annual maximum daily precipitation (RX1day, in mm) at the different stations.
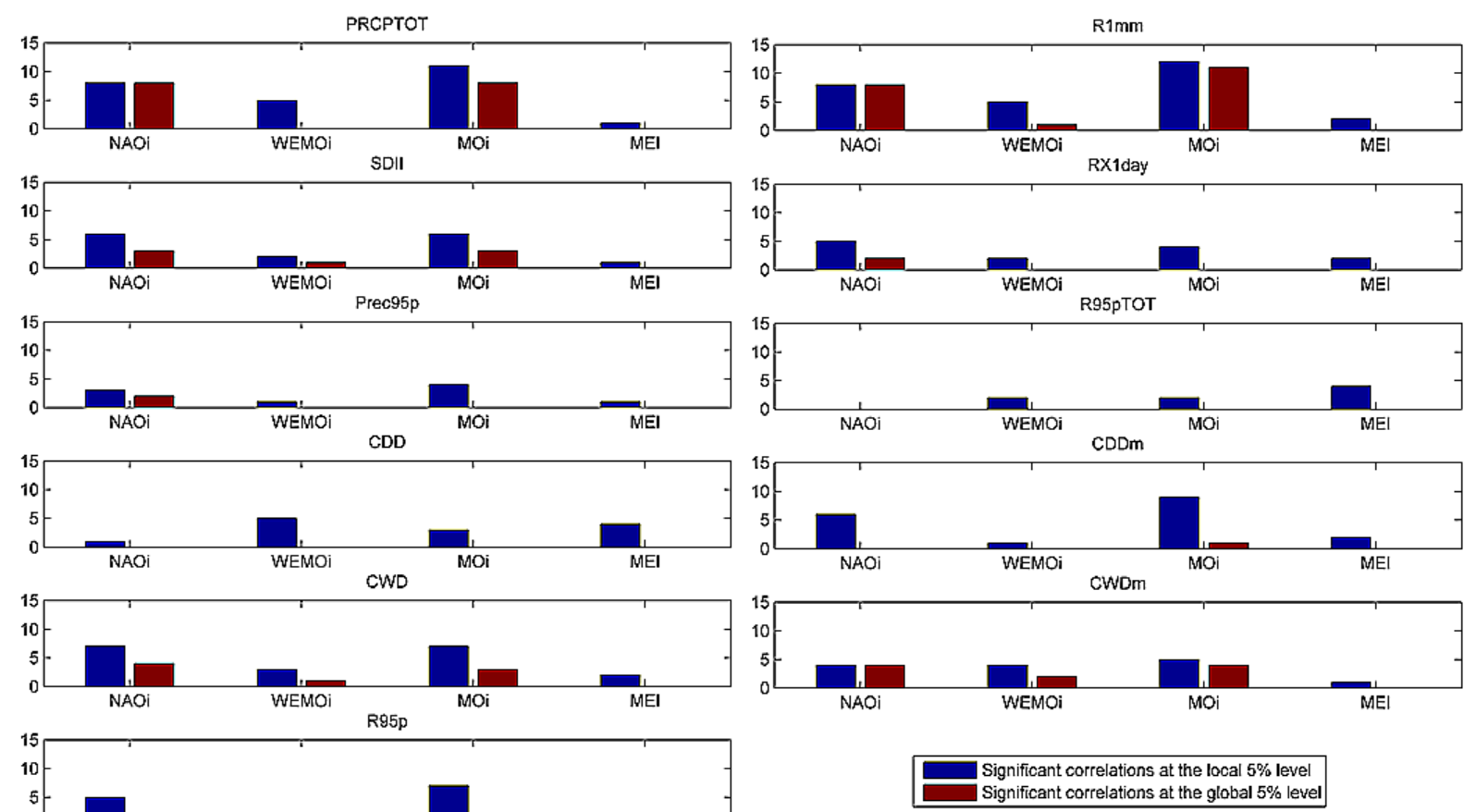

Fig. 9. Number of stations with significant correlations with the NAOi, WEMOi, MOi and MEi indices at the $5 \%$ local and global levels.

climatic indices. The PRCPTOT and R1mm indices and to a lesser extend SDII, CWD and CWDm, show field-significant correlations with NAOi, MOi and WEMOi. For PRCPTOT and $\mathrm{R} 1 \mathrm{~mm}$ the correlations with NAOi or MOi are significant in almost half of the stations if considering the local and global significance levels (Fig. 10), mostly in Morocco (Bab
Ouender, Mjaara, Beni Mellal, El Kansera, Larache, Tanger stations), Algeria (Ponteba station) but also in Tunisia with the MOi (Jendouba and Tunis stations). On average, the mean Spearman correlation coefficient between PRCPTOT at the different stations and NAOi is equal to -0.51 and -0.47 with 

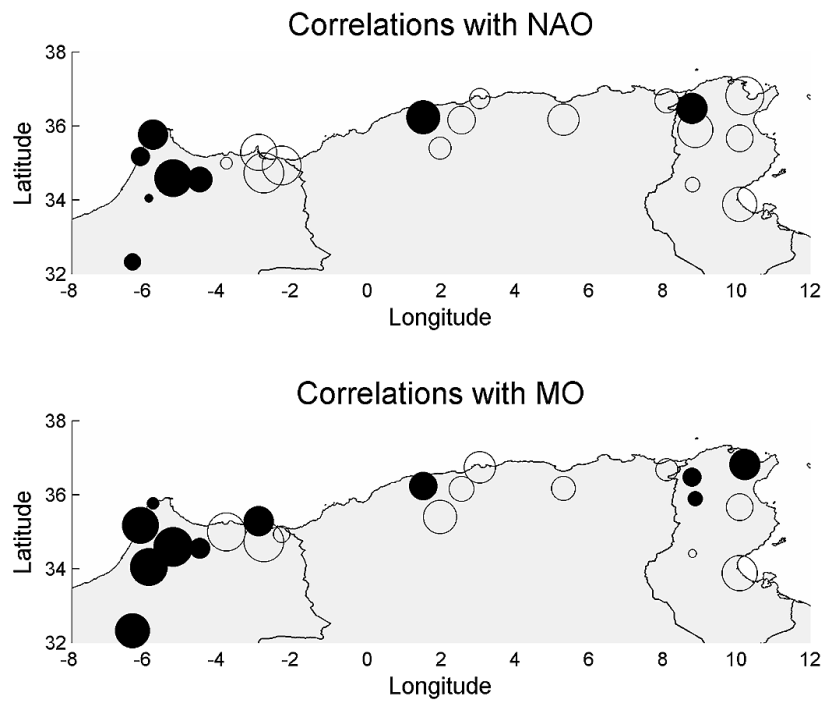

Fig. 10. Correlation between annual precipitation (PRCPTOT) and the NAOi and MOi indices at the different stations. The size of the circles is proportional to the Spearman correlation coefficients. The circles filled with black are the stations where the correlation is significant at the $5 \%$ level.

the MOi. For R1mm, the average correlation coefficient with NAOi is -0.5 and -0.48 with MOi.

These field-significant correlations support the findings of other studies demonstrating the impact of the NAOi or MOi on precipitation amounts, mainly in Morocco (El Hamly et al., 1998; Knippertz et al., 2003). Born et al. (2010) previously noted that large-scale variability controls Moroccan rainfall variability towards a detectable but relatively small range. Thus, they concluded that one should not expect these indices to deliver sufficient results for an assessment of seasonal rainfall prediction. This conclusion is supported by the results of the present study, with only moderate correlations found with NAOi or MOi (around -0.5 on average). A reasonable part of rainfall variability remains stochastic and can only be assessed by applying more complex atmospheric climate or weather prediction models (Born et al., 2010).

Finally, the heavy precipitation indices such as RX1day, Prec95p or R95pTOT are not strongly correlated with largescale circulation indices. Only a few field-significant correlations with the NAOi are detected for these indices, mainly for stations located in Morocco (Larache, Mjaara, Bab Ouender) as previously reported by Tramblay et al. (2012) or Donat et al. (2013). Indeed, the heavy rainfall events are caused by an interaction of several factors acting at different spatiotemporal scales: it is likely that large-scale circulation indices alone are not sufficient to characterize the variability of these extreme events

\section{Conclusions}

This study provides a regional assessment of trends in precipitation indices over Maghreb countries. Several precipitation indices describing precipitation amounts, heavy rainfall, and the duration of dry and wet periods have been computed for 22 stations having long data records of daily precipitation. There is a strong temporal and spatial variability, in particular for the indices describing the heavy precipitation events. On the other hand, the indices representing precipitation amounts or dry periods, such as the number of dry days or the duration of dry spells, show a greater spatial consistency, indicating that droughts periods are simultaneously impacting large areas. The influence of autocorrelation is found to be limited in the present analysis, but several indices show significant cross correlations among stations indicating the need to assess the field significance of trend results. The trend analysis indicates an increase of the dry episodes duration and magnitude, together with a decrease in the number of wet days and annual precipitation. For heavy precipitation, there is no such a strong signal towards a decrease or an increase, therefore the hypotheses of stationarity remain valid in most stations. These trends are significant at the regional scale and mostly affect Algeria and northern Morocco, while only a few local trends are detected in Tunisia. The detected trends for northern Africa are consistent with those found in other studies across the Mediterranean region (Brunetti et al., 2004; Costa et al., 2009; Meddi et al., 2010; Reiser and Kutiel, 2010; Caloiero et al., 2011; Schilling et al., 2012).

The precipitation indices considered in this study only show a moderate correlation with the various large-scale circulation indices considered. There is a dependence of annual precipitation or wet-day frequency with NAO and MO indices in almost half of the stations, but a very little correlation signal with the indices representing the heavy rainfall event magnitude or occurrence. Since heavy precipitation also exhibit a strong spatial variability among the different stations, it is hypothesized that these extreme events are more influenced by local climatic processes and topography. Although some spatial patterns for the different precipitation indices could be identified in the present analysis, to identify homogeneous regions there is a need to include more stations, even with shorter record length. These regional approaches could be useful to better analyze the influence of large-scale atmospheric circulation or to build robust downscaling methods for the assessment of future climate change impacts. 
Acknowledgements. This research project has been supported by the Institut de Recherche pour le Developpement (IRD, France); the financial support provided is gratefully acknowledged. The data sets have been provided by the Agence Nationale des Ressources Hydrauliques (Algeria), Direction de la Recherche et de la Planification de l'Eau (Morocco) and Direction Générale des Ressources en Eau (Tunisia). Special thanks are due to H. Ben-Mansour, R. Bouaicha, L. Behlouli, K. Benhattab, R. Taibi, K. Yaalaoui, for their helpful contribution in the database collection and to $\mathrm{S}$. Beguería who provided the NAO, WEMO and MO indices data. The authors wish to thank the associated editor, A. Mugnai, M. C. Llasat, M. Donat and the three anonymous reviewers for their useful comments.

Edited by: A. Mugnai

Reviewed by: three anonymous referees

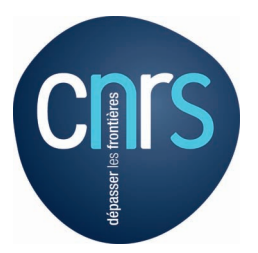

The publication of this article is financed by CNRS-INSU.

\section{References}

Acero, F. J., García, J. A., and Gallego, M. C.: Peaks-overThreshold Study of Trends in Extreme Rainfall over the Iberian Peninsula, J. Climate, 24, 1089-1105, 2011.

Alpert, P., Ben-Gai, T., Baharad, A., Benjamini, Y., Yekutieli, D., Colacino, M., Diodato, L., Ramis, C., Homar, V., Romero, R., Michaelides, S., and Manes, A.: The Paradoxical Increase of Mediterranean Extreme Daily Rainfall in Spite of Decrease in Total Value, Geophys. Res. Lett., 29, 1536, doi:10.1029/2001GL013554, 2002.

Angulo-Martínez, M. and Santiago Beguería, S.: Do atmospheric teleconnection patterns influence rainfall erosivity? A study of NAO, MO and WeMO in NE Spain, 1955-2006, J. Hydrol., 450451, 168-179, 2012.

Argence, S., Lambert, D., Richard, E., Chaboureau, J. P., and Söhne, N.: Impact of initial conditions uncertainties on the predictability of heavy rainfall in the Mediterranean: A case study, Quart. J. Roy. Meteor. Soc., 134, 1775-1788, 2008.

Bastin, G. B., Lorent, C., and Duque, M.: Optimal estimation of the average rainfall and optimal selection of raingage locations, Water Resour. Res., 20, 463-470, 1984.

Beaulieu, C., Ouarda, T. B. M. J., and Seidou, O.: A review of homogenization techniques for climate data and their applicability to precipitation series, Hydrol. Sci. J., 52, 18-37, 2007.

Beaulieu, C., Chen, J., and Sarmiento, J. L.: Change-point analysis as a tool to detect abrupt climate variations, Phil. T. R. Soc. A, 370, 1228-1249, 2012.

Benjamini, Y. and Hochberg, Y.: Controlling the false discovery rate: A practical and powerful approach to multiple testing, J. Roy. Stat. Soc. B, 57, 289-300, 1995.

Bonaccorso, B., Cancelliere, A., and Rossi, G.: Detecting trends of extreme rainfall series in Sicily, Adv. Geosci., 2, 7-11, doi:10.5194/adgeo-2-7-2005, 2005.
Bouaicha, R. and Benabdelfadel, A.: Variabilité et gestion des eaux de surface au Maroc, Sécheresse, 21, 1-5, 2010.

Born, K., Fink, A. H., and Knippertz, P.: Meteorological processes influencing the weather and climate of Morocco, in: Impacts of Global Change on the Hydrological Cycle in West and Northwest Africa, edited by: Speth, P., Christoph, M., and Diekkgrüger, B., ISBN: 978-3-642-12956-8, Springer, Heidelberg Dordrecht London New York, 2010.

Brunetti, M., Buffoni, L., Mangianti, F., Maugeri, M., and Nanni, T.: Temperature, precipitation and extreme events during the last century in Italy, Global Planet. Change, 40, 141-149, 2004.

Caloiero, T., Coscarelli, R., Ferrari, E., and Mancini, M.: Trend detection of annual and seasonal rainfall in Calabria (Southern Italy), Int. J. Climatol., 31, 44-56, 2011.

Conte, M., Giuffrida, A., and Tedesco, S: The Mediterranean Oscillation. Impact on precipitation and hydrology in Italy Climate Water, Publications of the Academy of Finland, Helsinki, 1989.

Costa, A. C. and Soares, A.: Trends in extreme precipitation indices derived from a daily rainfall database for the South of Portugal, Int. J. Climatol., 29, 1956-1975, 2009.

Di Baldassarre, G., Montanari, A., Lins, H., Koutsoyiannis, D., Brandimarte, L., and Blöschl, G.: Flood fatalities in Africa: From diagnosis to mitigation, Geophys. Res. Lett., 37, L22402, doi:10.1029/2010GL045467, 2010.

Douglas, E. M., Vogel, R. M., and Kroll, C. N.: Trends in floods and low flows in the United States: Impact of spatial correlation, J. Hydrol., 240, 90-105, 2010.

Douglas, I., Kurshid, A., Maghenda, M., McDonnell, Y., McLean, L., Campbell, J.: Unjust waters: climate change, flooding and the urban poor in Africa, Environ. Urban., 20, 187-205, 2008.

Donat, M. G., Peterson, T. C., Brunet, M., King, A. D., Almazroui, M., Kolli, R. K., Boucherf, D., Al-Mulla, A. Y., Youssouf Nour, A., Aly, A. A., Nada, T.A. A., Al Dashti, H. A., Salhab, T. G., El Fadli, K. I., Muftah, M. K., Eida, S. D., Badi, W., Driouech, F., El Rhaz, K., Abubaker, M. J. Y., Ghulam, A. S., Sanhouri Erayah, A., Mansour, M. B., Alabdouli, W. O., and Al Shekaili, M. N.: Changes in extreme temperature and precipitation in the Arab region: long-term trends and variability related to ENSO and NAO, Int. J. Climatol., doi:10.1002/joc.3707, 2013.

Driouech, F., Déqué, M., Sanchez-gomez, E.: Weather regimes Moroccan precipitation link in a regional climate change simulation, Global Planet. Change, 72, 1-10, 2010.

Driouech, F., Ben Rached, S., and El Heirech, T.: Climate variability and Change in North African Countries. In: Climate Change and Food Security in West Asia and North Africa, Springer Netherland, 161-172, doi:10.1007/978-94-007-6751-5_9, 2013.

El Hamly, M., Sebbari, R., Lamb, P., Ward, M. N., and Portis, D. H.: Towards the seasonal prediction of Moroccan precipitation and its implications for water resources management, Water Resources Variability in Africa During the XX Century: Proceeding of the Abidjan 98 Conference, 252. IAHS Publ, 79-87, 1988.

Gallego, M. C., Trigo, R. M., Vaquero, J. M., Brunet, M., García, J. A., Sigró, J., and Valente, M. A.: Trends in frequency indices of daily precipitation over the Iberian Peninsula during the last century, J. Geophys. Res., 116, D02109, doi:10.1029/2010JD014255, 2011.

Guillaud, C. and Trabelsi, M.: Gestion des ressources hydriques en Tunisie centrale: Les projets Sidi Saad et El Haouareb, Hydrology for the water management of large river basins, proceedings 
of the Vienna symposium, August 1991, IAHS Pub. 201, 1291381991.

Hamed, K. H. and Rao, A. R.: A modified Mann-Kendall trend test for autocorrelated data, J. Hydrol., 204, 182-196, 1998.

Hidalgo-Muñoz, J. M., Argüeso, D., Gámiz-Fortis, S. R., EstebanParra, M. J., and Castro-Díez, Y.: Trends of extreme precipitation and associated synoptic patterns over the southern Iberian Peninsula, J. Hydrol., 409, 497-511, 2011.

Hoerling, M., Eischeid, J., Perlwitz, J., Quan, X., Zhang, T., and Pegion, P.: On the Increased Frequency of Mediterranean Drought, J. Climate, 25, 2146-2161, 2012.

Hurrell, J. W.: Decadal Trends in the North Atlantic Oscillation: Regional Temperatures and Precipitation, Science, 269, 676-679, 1995.

Khaliq, M. N., Ouarda, T. B. M. J, Gachon, P., Sushama, L., and StHilaire, A.: Identification of hydrological trends in the presence of serial and cross correlations: A review of selected methods and their application to annual flow regimes of Canadian rivers. J. Hydrol., 368, 117-130, 2009.

Klein Tank, A. M. G., Wijngaard, J. B., Können, G.P., Böhm, R., Demarée, G., Gocheva, A., Mileta, M., Paschiardis, S., Hejkrlik, L., Kern-Hansen, C., Heino, R., Bessemoulin, P., MüllerWestermeier, G., Tzanakou, M., Szalai, S., Palsdottir, T., Fitzgerald, D., Rubin, S., Capaldo, M., Maugeri, M., Leitass, A., Bukantis, A., Aberfeld, R., van Engelen, A. F. V., Førland, E., Mietus, M., Coelho, F., Mares, C., Razuvaev, V., Nieplova, E., Cegnar, T., Lopez, A. J., Dahlström, B., Moberg, A., Kirchhofer, W., Ceylan, A., Pachaliuk, O., Alexander, L. V., and Petrovic, P.: New daily dataset of surface air temperature and precipitation observations for European Climate Assessment, Int. J. Climatol. 22, 14411453, 2002.

Kingumbi, A., Bargaoui, Z., and Hubert, P.: Investigation of the rainfall variability in central Tunisia, Hydrol. Sci. J., 50, 493 508, 2005.

Knippertz, P., Christoph, M., and Speth, P.: Long-termprecipitation variability inMorocco and the link to the large-scale circulation in recent and future climates, Meteorol. Atmos. Phys., 83, 67-88, 2003.

Lebel, T. and Laborde, J. P.: A geostatistical approach for areal rainfall statistics, Stochastic. Hydrol. Hydraul., 2, 245-261, 1988.

Lionello, P. (Ed.): The Climate of the Mediterranean Region, from the past to the future, ISBN: 9780124160422, Elsevier, Amsterdam, Netherlands, 2012.

Livezey, R. E. and Chen, W. Y.: Statistical field significance and its determination by Monte Carlo techniques, Mon. Weather Rev., 111, 46-59, 1983.

Llasat, M. C., Llasat-Botija, M., Prat, M. A., Porcú, F., Price, C., Mugnai, A., Lagouvardos, K., Kotroni, V., Katsanos, D., Michaelides, S., Yair, Y., Savvidou, K., and Nicolaides, K.: High-impact floods and flash floods in Mediterranean countries: the FLASH preliminary database, Adv. Geosci., 23, 47-55, doi:10.5194/adgeo-23-47-2010, 2010.

Lopez-Moreno, J. I., Vicente-Serrano, S. M., Angulo-Martínez, M., Beguería, S., Kenawy, A.: Trends in daily precipitation on the northeastern Iberian Peninsula, Int. J. Climatol., 30, 1026-1041, 2010.

Mann, H. B.: Nonparametric tests against trend, Econometrica, 13, 245-259, 1945.
Mariotti, A. and Dell'Aquila, A.: Decadal climate variability in the Mediterranean region: roles of large-scale forcings and regional processes, Clim. Dynam., 38, 1129-1145, 2012.

Martín-Vide, J. and Lopez-Bustins, J. A.: The Western Mediterranean Oscillation and rainfall in the Iberian Peninsula, Int. J. Climatol., 26, 1455-1475, 2006.

Mebarki, A.: Apport des cours d'eau et cartographie du bilan hydrologique: cas des bassins de l'Algerie orientale, Sécheresse, 21, 301-308, 2010.

Meddi, M. M., Assani, A. A., and Meddi, H.: Temporal Variability of Annual Rainfall in the Macta and Tafna Catchments, Northwestern Algeria, Water Resour. Manage., 24, 3817-3833, 2010.

Moberg, A. and Jones, P. D.: Trends in indices for extremes in daily temperature and precipitation in central and western europe, 1901-99, Int. J. Climatol., 25, 1149-1171, 2005.

New, M., Hewitson, B., Stephenson, D. A., Tsiga, A., Kruger, A., Manhique, A., Gomez, B., Coelho, C. A. S., Masisi, D. N., Kululanga, E., Mbambalala, E., Adesina, F., Saleh, H., Kanyanga, J., Adosi, J., Bulane, L., Fortunata, L., Mdoka, M. L., and Lajoie, R.: Evidence of trends in daily climate extremes over southern and west Africa, J. Geophys. Res., 111, D14102, doi:10.1029/2005JD006289, 2006.

Ouachani, R., Bargaoui, Z., and Ouarda, T.: Power of teleconnection patterns on precipitation and streamflow variability of upper Medjerda Basin, Int. J. Climatol., 33, 58-76, 2013.

Palutikof, J. P.: Analysis of Mediterranean climate data: measured and modelled, in: Mediterranean Climate-Variability and Trends, edited by: Bolle, H. J., Springer-Verlag, Berlin, 133-153, 2003.

Pettitt, A. N.: A Non-Parametric Approach to the Change-Point Detection, Appl. Stat., 28, 126-135, 1979.

Poncet, J.: La "catastrophe" climatique de l'automne 1969 en Tunisie, Annales de Géographie, 79, 581-595, 1970.

Pujol, N., Neppel, L., and Sabatier, R.: Regional tests for trend detection in maximum precipitation series in the French Mediterranean region, Hydrol. Sci. J., 52, 956-973, 2007.

Reiser, H. and Kutiel, H.: Rainfall uncertainty in the Mediterranean: time series, uncertainty, and extreme events, Theor. Appl. Climatol., 104, 357-375, 2011.

Renard, B., Lang, M., Bois, P., Dupeyrat, A., Mestre, O., Niel, H., Sauquet, E., Prudhomme, C., Parey, S., Paquet, E., Neppel, L., and Gailhard, J.: Regional methods for trend detection: Assessing field significance and regional consistency, Water Resour. Res., 44, W08419, doi:10.1029/2007WR006268, 2008.

Rodrigo, F. S.: Changes in the probability of extreme daily precipitation observed from 1951 to 2002 in the Iberian Peninsul, Int. J. Climatol., 30, 1512-1525, 2010.

Saidi, M. E. M., Daoudi, L., Aresmouk, M. E. H, Blali, A.: Rôle du milieu physique dans l'amplification des crues en milieu montagne montagnard : exemple de la crue du 17 août 1995 dans la vallée de 1'Ourika (Haut-Atlas, Maroc), Sécheresse, 14, 1-8, 2003.

Schilling, J., Freier, K. P., Hertig, E., and Scheffran, J.: Climate change, vulnerability and adaptation in North Africa with focus on Morocco, Agr. Ecosyst. Environ., 156, 12-26, 2012.

Servat, E., Paturel, J. E., Lubès-Niel, H., Kouamé, B., Masson, J. M., Travaglio, M., and Marieu, B.: De différents aspects de la variabilité de la pluviométrie en Afrique de l'Ouest et Centrale non sahélienne, Revue des Sciences de l'eau, 12, 363-387, 1999. 
Sen, P. K.: Estimates of the regression coefficient based on Kendall's tau, J. Am. Stat. Assoc., 63, 1379-1389, 1968.

Sousa, P. M., Trigo, R. M., Aizpurua, P., Nieto, R., Gimeno, L., and Garcia-Herrera, R.: Trends and extremes of drought indices throughout the 20th century in the Mediterranean, Nat. Hazards Earth Syst. Sci., 11, 33-51, doi:10.5194/nhess-11-33-2011, 2011.

Spearman, C.: The Proof and Measurement of Association between Two Things, Am. J. Psychol., 15, 72-101, 1904.

Toreti, A., Xoplaki, E., Maraun, D., Kuglitsch, F. G., Wanner, H., and Luterbacher, J.: Characterisation of extreme winter precipitation in Mediterranean coastal sites and associated anomalous atmospheric circulation patterns, Nat. Hazards Earth Syst. Sci., 10, 1037-1050, doi:10.5194/nhess-10-1037-2010, 2010.

Tramblay, Y., Badi, W., Driouech, F., El Adlouni, S., Neppel, L., and Servat, E.: Climate change impacts on extreme precipitation in Morocco, Global Planet. Change, 82-83, 104-114, 2012.

Tramblay, Y., Neppel, L., Carreau, J., and Najib, K.: Non-stationary frequency analysis of heavy rainfall events in southern France, Hydrol. Sci. J., 58, 1-15, 2013.

Ventura, V., Paciorek, C. J., and Risbey, J. S.: Controlling the proportion of falsely rejected hypotheses when conducting multiple tests with climatological data, J. Climate, 17, 4343-4356, 2004.
Villarini, G., James, J. A., Ntelekos, A. A., and Schwarz, U.: Annual maximum and peak-over-threshold analyses of daily rainfall accumulations for Austria, J. Geophys. Res., 116, D05103, doi:10.1029/2010jd015038, 2011.

Wijngaard, J. B., Klein Tank, A. M. G., and Können, G. P.: Homogeneity of 20th century european daily temperature and precipitation series, Int. J. Climatol., 23, 679-692, 2003.

Wilks, D. S.: On "field significance" and the false discovery rate, J. Appl. Meteorol. Climatol., 45, 1181- 1189, 2006.

Wolter, K. and Timlin, M. S.: El Niño/Southern Oscillation behaviour since 1871 as diagnosed in an extended multivariate ENSO index (MEI.ext), Int. J. Climatol., 31, 1074-1087, 2011.

Xoplaki, E., Gonzalez-Rouco, F. J., Luterbacher, J., and Wanner, H.: Wet season Mediterranean precipitation variability: influence of large-scale dynamics, Clim. Dynam., 23, 63-78, 2004.

Yue, S. and Wang, C. Y.: The Mann-Kendall test modified by effective sample size to detect trend in serially correlated hydrological series, Water Res. Manage. 18, 201-218, 2004.

Zhang, X., Aguilar, E., Sensoy, S., Melkonyan, H., Tagiyeva, U., Ahmed, N., Kutaladze, N., Rahimzadeh, F., Taghipour, A., Hantosh, T. H., Alpert, P., Semawi, M., Ali, M. K., Al-Shabibi, M. H. S., Al-Oulan, Z., Zatari, T., Al Dean Khelet, I., Hamoud, S., Sagir, R., Demircan, M., Eken, M., Adiguzel, M., Alexander, L., Peterson, T. C., and Wallis, T.: Trends in Middle East climate extreme indices from 1950 to 2003, J. Geophys. Res., 110, D22104, doi:10.1029/2005JD006181, 2005. 